This item was submitted to Loughborough's Research Repository by the author.

Items in Figshare are protected by copyright, with all rights reserved, unless otherwise indicated.

\title{
Building team brand equity through perceived CSR: the mediating role of dual identification
}

PLEASE CITE THE PUBLISHED VERSION

https://doi.org/10.1080/0965254X.2020.1795912

\section{PUBLISHER}

Taylor \& Francis (Routledge)

\section{VERSION}

AM (Accepted Manuscript)

\section{PUBLISHER STATEMENT}

This is an Accepted Manuscript of an article published by Taylor \& Francis in Journal of Strategic Marketing on 20 July 2020, available online: http://www.tandfonline.com/10.1080/0965254X.2020.1795912.

\section{LICENCE}

CC BY-NC-ND 4.0

\section{REPOSITORY RECORD}

Kim, Sungkyung, and Elisavet Manoli. 2020. "Building Team Brand Equity Through Perceived CSR: The Mediating Role of Dual Identification”. Loughborough University. https://hdl.handle.net/2134/12630554.v1. 
Building team brand equity through perceived CSR: the mediating role of dual identification

\author{
Sungkyung Kim \\ School of Sport, Exercise and Health Sciences \\ Loughborough University \\ Email: $\underline{\text { S.Kim@1boro.ac.uk }}$
}

\author{
Argyro Elisavet Manoli \\ School of Sport, Exercise and Health Sciences \\ Loughborough University \\ Leicestershire LE11 3TU, UK \\ Tel: +44 (0)1509 228453 \\ Email: E.A.Manoli@1boro.ac.uk
}




\title{
Building team brand equity through perceived CSR: the mediating role of dual
}

\section{identification}

\begin{abstract}
While involvement in CSR activities is common practice in today's sporting world, there is a need to go beyond the activities themselves to explore how fans' perceptions of CSR can affect customer-based brand equity and what role online-community and team identification can play in this relationship, which this study aims to explore. Data collected through an online survey of South Korean Samsung Lions baseball club fans (N=331), analysed through structural equation modelling, support the positive influence of perceived CSR on dual identification (team and online-community), and the impact of team identification on brand equity. Interestingly, CSR perception is shown to be an insignificant predictor of brand equity, influenced fully by team identification. This study suggests that promoting a sport team's socially responsible image is important in terms of building both team and online community identification while developing team identification can be vital in increasing the value of the sport brand.
\end{abstract}

\section{Keywords}

Corporate social responsibility; sport brand management; online community identification; team identification; baseball; structural equation modelling 


\section{Introduction}

Brand equity has emerged as a key theme underpinning the value of the brand. Corporate social responsibility (CSR) plays an important role not only in brand equity building but also in influencing consumers' supporting behavioural intentions (Hur, Kim, \& Woo, 2014; Martínez \& Nishiyama, 2017; Woo \& Jin, 2016). Within the context of sport, CSR can be nowadays considered a common trend in practice and a popular academic inquiry area, with extensive research on CSR in sport and its role in society (Chang, Ko, Connaughton, \& Kang, 2016). Sport provides an ideal environment for CSR promotion due to its social interaction and close connection with the local community (Manoli, 2015). However, empirical evidence of the formation of sport fan-based brand equity through fans' perception of CSR has yet to be explicitly studied.

Brand management literature supports that brand equity is largely predicated on customer-company identification (Bhattacharya \& Sen, 2003), while in sport, the effect of sport fans' identification towards a team on brand equity has drawn particular attention (Watkins, 2014; Wang \& Tang, 2018). However, there is scant research on identification with fans' online community in understanding brand equity despite the enormous value online communities yield sport entities. It is worth acknowledging that emotional attachment to the sport fans' community was shown to be a robust predictor of team identification and positive behavioural intentions such as future attendance (Yoshida, Heere, \& Gordon, 2015). Furthermore, the use of online-based communication techniques by sport organisations to communicate team and player news in real-time has enabled them to promote CSR initiatives further and quicker, allowing them to influence perception and attitude of sport fans (Morrison, Misener, \& Mock, 2018).

It is also worth noting that sport fans have multiple relationships within a community: horizontal relationships between fans and vertical relationships with the team they support. 
Although building the horizontal connection, fan-to-fan relationships, is sometimes more important than the vertical connection in understanding fan behaviour, there are few empirical studies to support the idea (Katz \& Heere, 2015; Katz, Ward, \& Heere, 2018). Moreover, given the fact that an individual can develop multiple identities in the process of becoming a sport fan, it is crucial to examine the formation of sport team brand equity from the multiple targets of identification (Wang \& Tang, 2018). Since members in the online community intrinsically connected with the team, identification with the community and the team should be distinguished. By doing so, brand managers of sport teams can design different strategies depending on the different targets of identification. Despite the fact that the firm and the intertwined link between an organisation (team), consumer (fan) and community (Walker \& Kent, 2009), online community identification is still a missing piece of the puzzle in that relationship.

To fill these gaps, this study aims to investigate the links among perceived CSR, fan's team and online community identification, and brand equity, in an attempt to further our understanding of building and managing customer-based brand equity for sport organisations. The manuscript is structured as follows; first, the existing literature linking the four areas is reviewed, before the hypotheses and the conceptual framework of our study are presented. Next, the sample, data collection and measurement details are outlined. Then the results of our study are presented before its implications and limitations are considered while highlighting future research avenues.

\section{Literature review and hypotheses development}

\section{CSR and team identification}

Identification towards a sport team has its academic roots in social identity theory, indicating an individual's perception that they belong to a social group. At the same time, social identity 
theory is often seen as an outcome of CSR. Organisations put much effort into promoting diverse CSR initiatives to meet the expectations of society and to encourage consumers to build a level of social identity with them (Manoli, 2015; 2018). Several empirical studies have confirmed that a sport team's CSR activities will result in enhancing the fan's identification with the team (Chang et al., 2016; Morrison et al., 2018). Chang et al. (2016) explored the structural relationship among sport fans' perceived CSR of teams, team identification and pride. According to the results, although CSR was not directly related to team identification, pride played a mediating role in this relationship, thus creating a link between thw two. Support for linking sport teams' CSR promotion with team identification is also found in the work of Morrison et al. (2018), who tested the relationship between perception of CSR, team identification and spectator behaviour. The results demonstrated that the mediation effect of team identification on CSR and patronage behaviour was partially significant, meaning that spectators become loyal to a team in the form of repeat purchase, media consumption, merchandise consumption and positive word-of-mouth when they perceive CSR programs through team identification. Similarly, Walker and Kent (2009) confirmed that sport fans had a sense of affiliation and favourable attitude when they were aware of their team's sustained participation in goodwill activities. Therefore, this study hypothesized that:

Hypothesis 1-1. Perception of CSR is positively associated with team identification.

\section{CSR and online community identification}

Little research exists examining how perceptions of CSR have an impact on forming and strengthening members' online sport fan community identification, despite the value of the online community as a great fan-to-fan communication platform. The online community is 
considered an effective way of marketing communication, shifting the focus from an off-line consumption experience to an online community-based experience ((Bhattacharya \& Sen, 2003). Online communities are places where beneficial long-term vertical connections and horizontal connections (Katz \& Heere, 2015) can be fostered simultaneously. Recently, the horizontal connection, fan-to-fan relationships, within communities has started gaining attention in the online community context. Yosida et al. (2015) identified that attachment towards the community is a more salient predictor of attendance than team identification. This finding is underpinned by Katz et al.'s (2018) result that fan's relationships with other fans are a stronger predictor of attendance than the relationship with the team.

Although the relationship between sport fans' perception of CSR and online community identification remains under-researched, it can be inferred from existing brand marketing studies. Recent research pointed out that online community identification is a major decisive factor of community members' attitude and behavioural intentions toward both the community and the brand (Popp \& Woratschek, 2017). For instance, identification with the online community has been identified as an immediate antecedent of loyalty and cooperation, trust and engagement, and community promotion (Kim \& Kim, 2017). Thus, the higher the levels of identification with a particular online community, the more expected the members are to be emotionally attached to the community, and the more likely they are to have a positive attitude and to be more loyal to both the community and the brand. Accordingly, the following hypothesis was proposed:

Hypothesis 1-2. Perception of CSR is positively associated with online community identification. 


\section{CSR and brand equity}

Sport teams' brand equity is often understood as the value that fans attach to the team they support and associate with its name, players and symbols (Gladden \& Milne, 1999). For sport branding, much of a team's value comes from fans' experiences of interacting with the team, and this experience builds brand awareness and associations that result in brand equity (Watkins, 2014). Understanding brand equity is, thus, useful for sport brand managers since it allows insight on how to influence their fans' association with the team (Gladden \& Milne, 1999).

Sport teams' CSR efforts are viewed as an antecedent of fan-based brand equity in the current study since sport consumers' perception of CSR activities is most likely associated with positive attitudes and behavioural intentions (e.g., loyalty, purchase intention), which are components of brand equity (Morrison et al., 2018; Walker \& Kent, 2009). Evidence of the link can be inferred from research focusing on different sectors (e.g. Woo \& Jin, 2016; Fatma et al., 2015), which have confirmed the efficacy of CSR initiatives on developing brand equity among consumers. Taking this lack of relevant research in sport brands into consideration, it is worth taking a look at the online fan community members' CSR-brand equity association for the expansion and further understanding of the area. Therefore, this study hypothesised a link between CSR and brand equity:

Hypothesis 2. Perception of CSR is positively associated with brand equity.

\section{Team identification and brand equity}

Watkins (2014) applied the social identity-brand equity (SIBE) model, originally developed by Underwood et al. (2001), in order to study the antecedents of brand equity in the context of professional sport, revealing that salient group, community group and venue are found to 
be predictors of fan identification, and this fan identification has a significant impact on customer-based brand equity. Through the results, the study highlighted a consumer-brand relationship that can facilitate brand equity, which is increased by fans' connection to the team (Watkins, 2014). Wang and Tang (2018) extended Watkins' (2014) research framework by proposing a dual identification model (identification with sport team and identification with sport team brand) to examine the dual identification as an antecedent of sport team brand equity. Wang and Tang (2018) tested both sport team and sport team identification since professional baseball teams in Taiwan are run by a wider umbrella company, whose name is even used as part of the team's name. Their results indicated that both sport team identification and sport team brand identification were significant predictors of sport team brand equity. The study confirmed that identification with a team and with a brand concurrently create sport team brand equity.

Boyle and Magnusson (2007) also adopted the SIBE model as a conceptual framework and classified a college team's fan groups into current students, alumni and the general public. Their empirical assessment contributed to validating the model, confirming the effect of social identity on brand equity. Wear et al. (2016) focused on the brand equity of sportswear companies' sponsorship and postulated that students' identification with a university and a sport team are associated with multi-dimensional brand equity, which consists of perceived quality, brand awareness and brand loyalty. The results lend a counterintuitive finding; both team identification and university identification are not statistically significant antecedents of brand equity. Thus, further testing the model in various contexts is needed in order for the relationship to be clarified, leading to the following hypothesis:

Hypothesis 3-1. Team identification is positively associated with brand equity. 


\section{Online community identification and brand equity}

Despite the enormous value that an online community can yield on sport organisations in terms of enhancing its brand equity and being a communication tool (e.g., promoting a team's CSR activities), online community identification has been neglected in exploring a team's brand equity, with the relationship between online community identification and sport team brand equity yet to be explored. It is, thus, critical to state the reasons why this study considers online community identification as a determinant of brand equity. This is because identification with online community is associated with the fact that the online community offers a space where a brand or organisation can build an ideal long-term symmetric relationship, ultimately, creating a significant positive impact on brand equity with their key public (Boyle \& Magnusson, 2007), while enhancing the significantly important fan-to-fan relationships (Katz \& Heere, 2015).

There are empirical studies that provide evidence in understanding more in-depth how 'community' centric identification translates to 'team' centric brand equity. Jang et al. (2008) established a hypothesis that stimulating community commitment would be expected to lead to brand loyalty, which is related to the concept of brand equity. Popp and Woratschek (2017) also made a critical assumption that can support the link between community-level outcomes and brand-level outcomes. They postulated that community loyalty has an impact on brand loyalty, and positive word-of-mouth intention towards the community is associated with word-of-mouth intention towards the brand. In line with these studies, Bagozzi and Dholakia (2006) also contended that "social identity with the brand community can contribute to the participant's identification with the brand" (p. 59). This is because extra benefits that community members might have such as a relationship with and within the community or sharing information will result in members' loyalty to the brand. Given the previously 
outlined fact that individual's relationships with the community consequently transform to brand-level outcomes and reinforce positive outcomes towards the brand, it is assumed that identification that is found in an online sport fan community can lead to a team's brand equity as it is part of the psychological experience of being a fan. This study examines a possible direct impact of online community identification on brand equity as an exploratory hypothesis. Taking this into consideration, the following hypothesis of this study is formed:

Hypothesis 3-2. Online community identification is positively associated with brand equity.

The mediating effect of online community identification between perceived CSR and brand equity

Individuals' identification is reported to be a significant predictor of brand equity (Wang \& Tang, 2018; Watkins, 2014), as well as an outcome of an organisation's CSR activities (Morrison et al., 2018). However, Woo and Jin's (2016) study reveals that perceiced CSR activities can have an insignificant impact on brand equity. This counterintuitive result implies the existence of alternative factors, such as online community identification, that may mediate the relationship between perceived CSR and brand equity. While Fatma et al. (2015) tested trust and Singh and Verma (2017) examined brand awareness, brand image, brand loyalty and purchase intention as mediators on the link between CSR and brand equity, investigating a mediation effect of online community identification has been neglected, even though identification plays an undeniably important role in understanding sport fans. Taking this into consideration, the indirect effect of CSR perception on brand equity through sport 
fans' identification with team and online community is examined, leading to the following hypotheses:

Hypothesis 4-1. Perception of a team's CSR and brand equity are mediated by fan identification.

Hypothesis 4-2. Perception of a team's CSR and brand equity are mediated by online community identification.

The conceptual framework of this study is illustrated in Figure 1.

Insert Figure 1 about here

\section{Methodology}

Sample and data collection

The fans of the South Korean Baseball Organisation's (KBO) Samsung Lions baseball club were chosen as the focus of our research. Both the Samsung Lions and the online fan community of the team represent the most famous baseball club and fan community in South Korea, having won the league eight times. The online community provides a platform for fans to communicate with other fans, share the news, discuss their team's management, share their experiences, analyse games result and plan group activities to cheer their team. The community was established in 2006 by fans, with nearly 53,000 members and over 500,000 posts uploaded by fans as of December 2019. 
Since this study focuses on sport fans' perception in an online community context, a web-based survey was deemed the most effective way for data collection. Although online surveys have several inherent disadvantages such as a potential low response rate, and possible difficulties in terms of access and generating a sample from an online community (Wright, 2005), the authors was able to minimise the potential issues due to the support of the managers of the community. The questionnaire was posted on a notice board of the online fan community between June 13th and July 11th, 2018, so that all members could access it. Of the 339 questionnaires collected, eight were discarded due to incomplete responses, resulting in obtaining 331 usable responses for this study.

\section{Measurement}

Multi-item scales were applied to assess each of the variables. For measuring the variables established in this research model, scales were adapted from previous studies (see Table 2 for items used). Sport fans' perceptions of CSR activities were measured using the Consumer Attitudes toward Responsible Entities in Sport (CARES) scale developed by Walker and Heere (2011). While the CARES is originally a two-dimensional scale (i.e., cognitive awareness and affective evaluation) with seven items, cognitive awareness consisting of three items was adopted in the current study. The reason for adopting the CARES scale is that it was specifically developed for the sport context. To assess the sport fans' identification with the online community, five items established by Algesheimer et al. (2005) were applied. To assess the team identification, seven items from the Sport Spectator Identification Scale developed by Wann and Branscombe (1993) were used. Measures for brand equity were adopted from Watkins (2014), who examined customer-based brand equity on the basis of the SIBE model, which underpins the causal relationship between social identity theory and brand equity in this study. See Table 2 for more information on the sample items. 
Using back-translation, two academics fluent in both Korean and English translated the measurement items. Five-point Likert scales ranging from "strongly disagree" (1) to "strongly agree (5) were used for all items. Additionally, a pilot test was conducted prior to the main survey, in order to ensure its reliability and the accuracy of the expressions used. Collected data were analysed using SPSS for descriptive statistics and AMOS for structural modelling.

\section{Results}

Sample

Insert Table 1 about here

\section{Measurement model}

Prior to examining the reliability and validity of the sample, a preliminary analysis was carried out to identify multivariate normality. The current study detects outliers based on Mahalanobis distance using SPSS 23.0 (Pallant, 2010). A total of 26 samples that had Mahalanobis distance values ranging from 22.72 to 91.34 were detected as outliers and removed for the next analysis.

To validate the measurement model, convergent validity, discriminant validity and reliability testing were undertaken. First, three methods were used to verify the convergent validity: standardised factor loading, average variance extracted (AVE) and composite reliability (CR). Items showed standardised factor loading below .7 (C.R. > 1.965, p < .05) were removed, while retaining 13 items for 4 constructs that exceeded the minimum requirements as shown in Table 2 (Bagozzi \& Yi, 1988). In this study, the AVE value for 
each of the constructs was $.74, .78, .67$ and .75 , exceeding the recommended .5 threshold. The CR value for four constructs was ranging from .85 to .92 , all of which being greater than the recommended .6 threshold (Bagozzi \& Yi, 1988). Also, the reliability of the constructs was accessed based on Cronbach's alpha coefficients. With the coefficients ranging from .77 to .87 , the constructs used in this study proved to have adequate reliability, exceeding the recommended .7 threshold (Anderson \& Gerbing, 1988). Goodness-of-fit of the measurement model indices $(\mathrm{CMIN} / \mathrm{DF}=1.42, \mathrm{RMR}=.02, \mathrm{GFI}=.96, \mathrm{AGFI}=.94 . \mathrm{NFI}=.95, \mathrm{IFL}=.97$, $\mathrm{TLI}=.98, \mathrm{CFI}=.98, \mathrm{RMSEA}=.04)$ reflected an excellent model fit. See Table 2 for detailed information on the validity assessments of content and the goodness-of-fit statistics.

Insert Table 2 about here

Lastly, the discriminant validity of the constructs was accessed by comparing the AVE and the square root of correlations between constructs. Discriminant validity is a concept that compares an explanation of latent variable and observed variable with an explanation of between latent variables. If the AVE of a certain construct is greater than the square foot of the correlations between this construct and the other constructs, then discriminant validity is ensured (Hair et al., 1998). As shown in Table 3, the results showed that all square roots of the correlations between constructs were less than the AVE for each construct, therefore, achieving satisfactory discriminant validity between constructs.

Insert Table 3 about here 


\section{Structural model and hypotheses testing}

AMOS 20.0 software was used to conduct structural equation modelling in our study. The goodness of fit indices of the structural model was acceptable $(\mathrm{CMIN} / \mathrm{DF}=2.98, \mathrm{RMR}=.02$, $\mathrm{GFI}=.98, \mathrm{AGFI}=.89 . \mathrm{NFI}=.94, \mathrm{IFL}=.95, \mathrm{TLI}=.88, \mathrm{CFI}=.95, \mathrm{RMSEA}=.08)$. The direct path linking fans' awareness of the team's CSR activities to team identification was significant $(\beta=.25, \mathrm{p}<0.001)$, suggesting that perception of CSR is an antecedent of team identification. The direct effect from the perception of CSR to the online community identification was also found to be strongly significant $(\beta=.33, \mathrm{p}<0.001)$, and therefore, hypothesis 1-1 and 1-2 were supported. The result showed that $11 \%$ of the total variance in community identification $\left(\mathrm{R}^{2}=.11\right)$ and $6 \%$ of the total variance in team identification $\left(\mathrm{R}^{2}\right.$ $=.06)$ were accounted for by fans' perceived CSR, respectively. Hypothesis 2 predicted that awareness of CSR would affect brand equity. The results indicated that the effect of perceived CSR on brand equity appeared insignificant $(\beta=.07, \mathrm{p}>0.05)$, hence, hypothesis 2 was rejected. Hypothesis 3-1 and Hypothesis 3-2 posited that team and online community identification would lead to brand equity, respectively. The direct effect from team identification to brand equity was found to be significant $(\beta=.56, \mathrm{p}<0.001)$, whereas online community identification was not positively associated with brand equity $(\beta=.04, p>0.05)$, and therefore failed to support Hypothesis 3-2. Dual identification and perception of CSR together explained $35 \%$ of the total variance in brand equity $\left(\mathrm{R}^{2}=.35\right)$.

The mediation role of dual identification, team identification and online community identification, was also examined. A bootstrap procedure was used to test the statistical significance of an indirect effect and resampled 5,000 times generating a 95\% bias-corrected confidence interval. The criterion for the mediation effect was judged by the exclusion of zero between the lower bound and upper bound of the confidence interval (Preacher \& 
Hayes, 2008). For instance, the presence of zero within the lower and upper bound of the confidence interval indicates no mediation effect. Hypothesis 4-1 postulated that team identification would mediate the direct link between perceived CSR and brand equity. The result indicated that the link between perception of CSR and brand equity was fully mediated by fan's team identification ( $\beta=.14,95 \%$ CI $.08-.21)$, hence, team identification can be considered a mediator between perceived CSR and brand equity. The indirect effect of awareness of CSR on brand equity through identification with the online community was insignificant $(\beta=.01,95 \% \mathrm{CI}-.02-.05)$, which does not support Hypothesis 4-2.

Insert Table 4 about here

\section{Discussion}

This study examined whether the perceived CSR activities of a baseball team may relate to its brand equity, while considering whether fans' multiple identifications may mediate this relationship. The findings of our study suggest that perception of sport teams' SCR initiatives can significantly influence fans' social identity towards both the online community and the team, similarly to how perceived CSR can influence team identification according to the study of Morrison et al. (2018). This result means that a sport team can build and enhance both vertical (i.e., fan-to-team) and horizontal (i.e., fan-to-fan) relationships by focusing on the promotion of their CSR activities. With sport fans' attitudes being influenced by ethically-oriented practices now more than ever, online sport fan communities can play a vital role in facilitating this CSR promotion, further assisting sport teams in strengthening vertical and horizontal relationships. Interestingly, this finding is inconsistent with previous 
research suggesting that CSR is not directly related to team identification, but is fully mediated by pride (Chang et al., 2016). Our findings, again, show direct links between perceived CSR and dual identifications, which are strong predictors of positive behavioural intentions such as loyalty (Kim \& Kim, 2017). In other words, the more sport fans perceive CSR, the more they identify with their team and online community. However, when it comes to the social identity-brand equity relationship, only one type of identification, team identification, had a significant impact on brand equity. Our results suggest that identification with a team was found to have a strong influence on brand equity in line with Watkins' (2014) and Wang and Tang's (2018) findings, showing the cause and effect between team identification and customer-based brand equity. Regarding the association between online community identification and brand equity, which was exploratively investigated, it revealed that there is no statistical evidence on the relationship. The under-researched relationship between perceived CSR and sport brand equity that was explored in this study demonstrates that, unlike Hur et al.'s (2014), Martínez and Nishiyama's (2017), and Woo and Jin's (2016) findings, the link between the two constructs does not exist. At the same time, identification with the team was found to be a full mediator between perceived CSR and brand equity. This implies that awareness of CSR initiatives does not lead to brand equity without sport fans' team identification, suggesting that sport fans attitude toward their team is a prerequisite of building brand equity. Its role in influencing brand equity and being influenced by perceived CSR lend themselves in highlighting the implications of this study and underline once more the need for further research on the area.

\section{Implications}

The findings of our study offer a number of practical implications for brand management of sport organisations. First, accepting the hypothesis that perceived CSR leads to dual- 
identifications of sport fans, both online community and team identification, indicates that being involved in and particularly promoting a sport organisation's CSR practices can help build the online community and team identification of the fans. In terms of the association of CSR with online community identification, developing and promoting CSR can assist sport organisations in making fans feel more attached to the team's online community while increasing their sense of a shared identity, which can, in turn, influence their fan behaviour (Popp \& Woratschek, 2017; Bhattacharya \& Sen, 2003). In other words, by making fans aware of the CSR activities, fans become more attached to the online community, which can lead to them having a positive attitude towards the sport organisation, and thus being more loyal to both the community and the brand (Kim \& Kim, 2017). In this sense, online sport fan community can be a useful communication platform for sport organisations to inform and promote their CSR practices. This implication is meaningful because sport brand managers often fail to realise the full potential of the consumer-created brand community. Brand managers have been often more focused on the marketer-created community than the consumer-created community while overlooking the fact that the consumer-created community facilitates fan-to-fan relationship building (Kats, Ward, \& Heere, 2018), which can reinforce their online community identification that has a positive long-term impact on the fan-brand relationship (Popp \& Woratschek, 2017).

Identification with a team was also shown to be a robust outcome of perceived CSR. Perception of CSR activity is a form of subjective measure that allows sport fans to consider their team as a better organisation than other teams, reflecting their self-identity to the team (Morrison et al., 2018). This implies that sport teams must care not only about their success on-field but also about their social contribution activities in order to secure strong team identification of fans. Given the strong effect of perceived CSR on multiple targets of identification, being perceived as socially responsible and establishing communication 
strategies that can effectively promote CSR practices should be considered the sport brand managers' priority.

Another important practical implication for brand managers of professional sport teams is the uncovered mediating role of team identification in the link between perceived CSR and brand equity, which indicates that fans' team identification significantly influences brand equity in sport organisations. Unlike previous research, the current study produced counterintuitive results indicating that perceived CSR practices are not directly associated with brand equity. This study found that the effect size of team identification on brand equity is more significant than any other relationship, while there exists a full mediation effect of team identification between CSR perception and brand equity, implying that sport fans' awareness of CSR would not result in brand equity without team identification. Perceiving the CSR practices of a team may allow sport fans to feel proud of their team, reinforcing their team identification and, ultimately, enhancing the brand equity of the team (Morrison et al., 2018). This finding suggests that team identification fully elucidates how CSR initiatives lead to building brand equity, underlying its significance for brand management in sport. Indeed, the findings of our study suggest that brand managers who aim to increase the value of a sport brand must focus on building team identification, due to both its direct relationship with brand equity and its mediating role between perceived CSR and brand equity.

In terms of its theoretical implications, this study focused on a structural causal relationship among perceived CSR, brand equity and dual identification of sport fans, while underlying the dual identification's mediating effect from the sport fans' perspective. This study contributes to the sport management literature by integrating CSR and the SIBE model with the under-studied multiple identifications of sport fans; online community identification and team identification. By showing a strong predictive relationship with team identification and sport team's brand equity, the results of $\mathrm{H}_{3-1}$ strongly support Underwood et al.'s (2001) 
SIBE model. Although the positive effect of online community identification on brand equity was insignificant, the study expands existing knowledge by examining multiple targets, which in turns leads to another theoretical implication.

To uncover the transition from community-level outcomes to brand (team)-level outcomes, this study considered whether the online community identification is transferred to a team's brand equity. While several studies on brand community have proposed adding hypotheses which assume the necessity of mediators for translating community-level outcomes to brand-level outcomes (Popp \& Woratschek, 2017), this study confirmed that online community identification is not directly related to brand equity which substantiates the need for the additional variable.

\section{Limitations and Future Research}

Despite its implications, there are of course limitations to the study. First, it involves a small sample, on a single baseball team in a single country. Although it is shown that causal claims can be made from the data through appropriate testing and the use of structural equation modelling, it follows that more longitudinal data are needed to explore the relations that are suggested in the study, while researching similar or less similar contexts. In the same vein, the sample used in this study is limited to cross-sectional data. Further studies could explore this issue while employing an experimental setting or focus group interviews which might be able to take a closer look into the synergistic effects of the interrelationships among the variables, while overcoming potential limitations that arise from the use of online surveys and self-administered questionnaires, e.g. bias and social desirability risks, correlational data.

Moreover, further research should be conducted in the emerging area of online community identification and its revealed and promising link with customer-based brand equity. Since the results of the current study indicate that promoting CSR activities through 
an online community and building the baseball teams' online fan community identification can be a valuable aim in marketing, it is, thus, encouraged that future research explores the area further, while studing other online communities and platforms.

\section{Conclusion}

To conclude, based on a primary data survey of the relationship between perceived CSR, online community identification, team identification and brand equity among fans of the Samsung Lions baseball club, this study showed that the more sport fans' are aware of a team's CSR program, the more they feel connected to a team, and the more identified they feel with the team and their community. Also, brand equity can be significantly influenced by the level of team identification of fans. The former would suggest that brand management in sport should focus on promoting a socially responsible image for the brand, while the latter indicates that emphasis should be put on developing highly identified fans. Both these aspects can be considered key in increasing the value of a sport brand and thus assisting sport brand managers against the increasing pressures of today's ultra-competitive sporting world. 


\section{References}

Algesheimer, R., Dholakia, U. M., \& Herrmann, A. (2005). The social influence of brand community: Evidence from European car clubs. Journal of Marketing, 69(3), 19-34.

Anderson, J. C., \& Gerbing, D.W. (1988). Structural equation modelling in practice: A review and recommended two-step approach. Psychological Bulletin, 103(3), 411423.

Bagozzi, R. P., \& Dholakia, U.M. (2006). Antecedents and purchase consequences of customer participation in small group brand communities. International Journal of Research in Marketing, 23(1), 45-61.

Bagozzi, R. P., \& Yi, Y. (1988). On the evaluation of structural equation models. Journal of the Academy of Marketing Science, 16(1), 74-94.

Bhattacharya, C.B., \& Sen, S. (2003). Consumer-company identification: A framework for understanding consumers' relationships with companies. Journal of Marketing, 67(2), $76-88$

Boyle, B. A., \& Magnusson, P. (2007). Social identity and brand equity formation: A comparative study of collegiate sports fans. Journal of Sport Management, 21(4), 497-520.

Chang, M. J., Ko, Y.J., Connaughton, D.P., \& Kang, J. H. (2016). The effects of perceived CSR, pride, team identification, and regional attachment: The moderating effect of gender. Journal of Sport \& Tourism, 20(2), 145-159.

Fatma, M., Rahman, Z., \& Khan, I. (2015). Building company reputation and brand equity through CSR: the mediating role of trust. International Journal of Bank Marketing, $33(6), 840-856$.

Gladden, J. M., \& Milne, G.R. (1999). Examining the importance of brand equity in professional sports. Sport Marketing Quarterly, 8, 21-30. 
Hur, W. M., Kim, H., \& Woo, J. (2014). How CSR leads to corporate brand equity: Mediating mechanisms of corporate brand credibility and reputation. Journal of Business Ethics, 125(1), 75-86.

Katz, M., \& Heere, B. (2015). Empowerment within brand communities: Overcoming the Achilles' Heel of scale-free networks. Sport Management Review, 18(3), 370-383.

Katz, M., Ward, R.M., \& Heere, B. (2018). Explaining attendance through the brand community triad: Integrating network theory and team identification. Sport Management Review, 21(2), 176-188.

Kim, M. S., \& Kim, H. M. (2017). The effect of online fan community attributes on the loyalty and cooperation of fan community members: The moderating role of connect hours. Computers in Human Behavior, 68, 232-243.

Manoli, A. E. (2015). Promoting corporate social responsibility in the football industry. Journal of Promotion Management, 21(3), 335-350.

Manoli, A. E. (2018) Sport marketing's past, present and future, Journal of Strategic Marketing. 26(1), 6-18.

Martínez, P., \& Nishiyama, N. (2017). Enhancing customer-based brand equity through CSR in the hospitality sector. International Journal of Hospitality \& Tourism Administration, 1-25.

Morrison, K. A., Misener, K. E., \& Mock, S. E. (2018). The influence of corporate social responsibility and team identification on spectator behavior in Major Junior Hockey. Leisure Sciences, 40(6), 1-19.

Pallant, J. (2010). SPSS Survival Manual. UK: McGraw-Hill Education.

Popp, B., \& Woratschek, H. (2017). Consumer-brand identification revisited: An integrative framework of brand identification, customer satisfaction, and price image and their 
role for brand loyalty and word of mouth. Journal of Brand Management, 24(3), 250270.

Preacher, K. J., \& Hayes, A.F. (2008). Asymptotic and resampling strategies for assessing and comparing indirect effects in multiple mediator models. Behavior Research Methods, 40(3), 879-891.

Singh, A., \& Verma, P. (2017). How CSR affects brand equity of Indian firms? Global Business Review, 18(3S), 52-69.

Underwood, R., Bond, E., \& Baer, R. (2001). Building service brands via social identity: Lessons from the sports marketplace. Journal of Marketing Theory and Practice, 9(1), 1-13.

Walker, M., \& Heere, B. (2011). Consumer attitudes toward responsible entities in sport (CARES): Scale development and model testing. Sport Management Review, 14(2), 153-166.

Walker, M., \& Kent, A. (2009). Do fans care? Assessing the influence of corporate social responsibility on consumer attitudes in the sport industry. Journal of Sport Management, 23(6), 743-769.

Wang, M. C. H., \& Tang, Y. Y. (2018). Examining the antecedents of sport team brand equity: A dual-identification perspective. Sport Management Review, 21(3), 293-306.

Wann, D. L., \& Branscombe, N. R. (1993). Sport fans: Measuring degree of identification with their team. International Sports Journal, 24, 1-17.

Watkins, B. A. (2014). Revisiting the social identity-brand equity model: An application to professional sports. Journal of Sport Management, 28(4), 471-480.

Wear, H., Heere, B., \& Clopton, A. (2016). Are they wearing their pride on their sleeve? examining the impact of team and university identification upon brand equity. Sport Marketing Quarterly, 25(2), 79-89. 
Woo, H., \& Jin, B. (2016). Culture doesn't matter? The impact of apparel companies' corporate social responsibility practices on brand equity. Clothing and Textiles Research Journal, 34(1), 20-36.

Yoshida, M., Heere, B., \& Gordon, B. (2015). Predicting behavioral loyalty through community: Why other fans are more important than our own intentions, our satisfaction, and the team itself. Journal of Sport Management, 29(3), 318-333. 
Table1

Respondents' Demographic Profile

\begin{tabular}{llcc}
\hline Profile & Description & Responses $(\mathrm{n}=331)$ & Percentage $(\%)$ \\
\hline Gender & Male & 217 & 65.6 \\
Age group & Female & 114 & 34.4 \\
& $18-25$ years & 87 & 26.3 \\
& 26-30 years & 74 & 22.4 \\
Occupation & $31-39$ years & 102 & 30.8 \\
& 40 years and above & 68 & 20.5 \\
& Student & 84 & 25.4 \\
& Part-time employee & 6 & 1.8 \\
& Full-time employee & 184 & 55.6 \\
& Self-employed & 11 & 3.3 \\
Highest educational & Retired & 2 & 0.6 \\
qualification & Other & 44 & 13.3 \\
& High school graduate & 120 & 36.3 \\
& Undergraduate degree & 186 & 56.2 \\
Questions for sample behaviour & 25 & 7.6 \\
\hline \multirow{4}{*}{ How long have you been } & Postgraduate degree & & \\
Lions' fan? & Under 1 year & 7 & 2.1 \\
& 4-6 years & 47 & 14.2 \\
& 7-9 years & 63 & 19.0 \\
How many times do you & More than 10 years & 179 & 11.8 \\
attend matches for a & Under 1 time & 9 & 52.9 \\
season? & 3-4 times & 32 & 2.7 \\
& 5-6 times & 70 & 9.7 \\
\hline & More than 7 times & 59 & 21.1 \\
& & 161 & 17.8 \\
& & & 48.6 \\
\hline
\end{tabular}


Table2

Results of Confirmatory Factor Analysis and Convergent Validity

\begin{tabular}{|c|c|c|c|c|c|}
\hline \multirow{2}{*}{$\begin{array}{l}\text { Constructs and } \\
\text { measurement items (Labels) }\end{array}$} & \multicolumn{2}{|c|}{$\begin{array}{l}\text { Confirmatory factor } \\
\text { analysis }\end{array}$} & \multirow{2}{*}{$\begin{array}{c}\text { Reliability } \\
\text { Alpha }\end{array}$} & \multicolumn{2}{|c|}{$\begin{array}{c}\text { Convergent } \\
\text { validity }\end{array}$} \\
\hline & $\begin{array}{l}\text { Factor } \\
\text { loading }\end{array}$ & $\begin{array}{c}\text { Critical } \\
\text { ratio (C.R.) }\end{array}$ & & $\mathrm{CR}$ & AVE \\
\hline Perceived CSR & & & \multirow{3}{*}{.86} & \multirow{3}{*}{.85} & \multirow{3}{*}{.74} \\
\hline $\begin{array}{l}\text { I am aware of the social programs of my } \\
\text { favourite team (CSR 1) }\end{array}$ & .89 & - & & & \\
\hline $\begin{array}{l}\text { I know of the good things my favourite team } \\
\text { does for the community (CSR 2) }\end{array}$ & .85 & $8.76^{* * *}$ & & & \\
\hline \multicolumn{3}{|l|}{ Team identification } & \multirow{4}{*}{.77} & \multirow{4}{*}{.91} & \multirow{4}{*}{.78} \\
\hline $\begin{array}{l}\text { I see myself as a strong fan of the Samsung } \\
\text { Lions? (TI 3) }\end{array}$ & .76 & - & & & \\
\hline $\begin{array}{l}\text { It is important for me to being a fan of the } \\
\text { Samsung Lions (TI } 4 \text { ) }\end{array}$ & .71 & $10.78^{* * *}$ & & & \\
\hline $\begin{array}{l}\text { My friends see me as a strong fan of the } \\
\text { Samsung Lions (TI 5) }\end{array}$ & .70 & $10.55^{* * *}$ & & & \\
\hline \multicolumn{3}{|l|}{ Online community identification } & \multirow{5}{*}{.87} & \multirow{5}{*}{.89} & \multirow{5}{*}{.67} \\
\hline I am very attached to the community (OCI 1) & .80 & - & & & \\
\hline I see myself as a part of the community (OCI 2) & .82 & $14.80^{* * *}$ & & & \\
\hline $\begin{array}{l}\text { The friendship I have with other community } \\
\text { members means a lot to me (OCI } 3 \text { ) }\end{array}$ & .79 & $14.28^{* * *}$ & & & \\
\hline $\begin{array}{l}\text { If community members planned something, I'd } \\
\text { think of it as something 'we' would do rather } \\
\text { than 'they' would do (OCI 5) }\end{array}$ & .74 & $13.23^{* * *}$ & & & \\
\hline \multicolumn{3}{|l|}{ Brand equity } & \multirow{5}{*}{.82} & \multirow{5}{*}{.92} & \multirow{5}{*}{.75} \\
\hline $\begin{array}{l}\text { I believe that overall, the team is a high quality } \\
\text { organisation (BE 3) }\end{array}$ & .70 & - & & & \\
\hline $\begin{array}{l}\text { Attending a team game is worth the time and } \\
\text { money to do so (BE 5) }\end{array}$ & .72 & $10.41^{* * *}$ & & & \\
\hline $\begin{array}{l}\text { I can recognise the team among other teams in } \\
\text { the league (BE 6) }\end{array}$ & .71 & $10.12^{* * *}$ & & & \\
\hline I can recall the team's logo quickly (BE 7) & .72 & $10.24^{* * *}$ & & & \\
\hline
\end{tabular}


Table3

Results of Discriminant Validity

\begin{tabular}{ccccc}
\hline & Perceived CSR & $\begin{array}{c}\text { Team } \\
\text { identification }\end{array}$ & $\begin{array}{c}\text { Online community } \\
\text { identification }\end{array}$ & Brand equity \\
\hline Perceived CSR & .74 & & & \\
\hline Team identification & .09 & .78 & .67 & .75 \\
\hline $\begin{array}{c}\text { Online community } \\
\text { identification }\end{array}$ & .14 & .09 & .06 & .59 \\
\hline Brand equity & .07 & .59 &
\end{tabular}

Note: The italicised cells present the values of the averaged variance extracted (AVE) 
Table4

Results of Hypotheses Test

\begin{tabular}{|c|c|c|c|}
\hline \multirow{2}{*}{ Hypothesis } & Direct effect & Indirect effect & \multirow{2}{*}{ Results } \\
\hline & $\beta(\mathrm{p})$ & $\beta\left(\mathrm{CI}_{\text {Low }}-\mathrm{CI}_{\text {High }}\right)$ & \\
\hline H1-1: Perceived CSR $\rightarrow$ Team identification & $.25^{* * *}$ & & Accepted \\
\hline $\begin{array}{l}\text { H1-2: Perceived CSR } \rightarrow \text { Online community } \\
\text { identification }\end{array}$ & $.33^{* * *}$ & & Accepted \\
\hline H2: Perceived CSR $\rightarrow$ Brand equity & $.07^{\text {n.s. }}$ & & Rejected \\
\hline H3-1: Team identification $\rightarrow$ Brand equity & $.56^{* * *}$ & & Accepted \\
\hline $\begin{array}{l}\text { H3-2: Online community identification } \rightarrow \\
\text { Brand equity }\end{array}$ & $.04^{\text {n.s. }}$ & & Rejected \\
\hline \multicolumn{4}{|l|}{ Proposed paths mediated by team identification } \\
\hline H4-1: Perceived CSR $\rightarrow$ Brand equity & & $.14(.08-.21)$ & Accepted \\
\hline \multicolumn{4}{|l|}{$\begin{array}{l}\text { Proposed paths mediated by online } \\
\text { community identification }\end{array}$} \\
\hline H4-2: Perceived CSR $\rightarrow$ Brand equity & & $.01(-.02-.05)$ & Rejected \\
\hline $\begin{array}{l}* \mathrm{p}<0.05, * * \mathrm{p}<0.01, * * * \mathrm{p}<0.001 \\
\text { Online community identification: } \mathrm{R}^{2}=.11, \text { Te }\end{array}$ & entificati & D & 35 \\
\hline
\end{tabular}




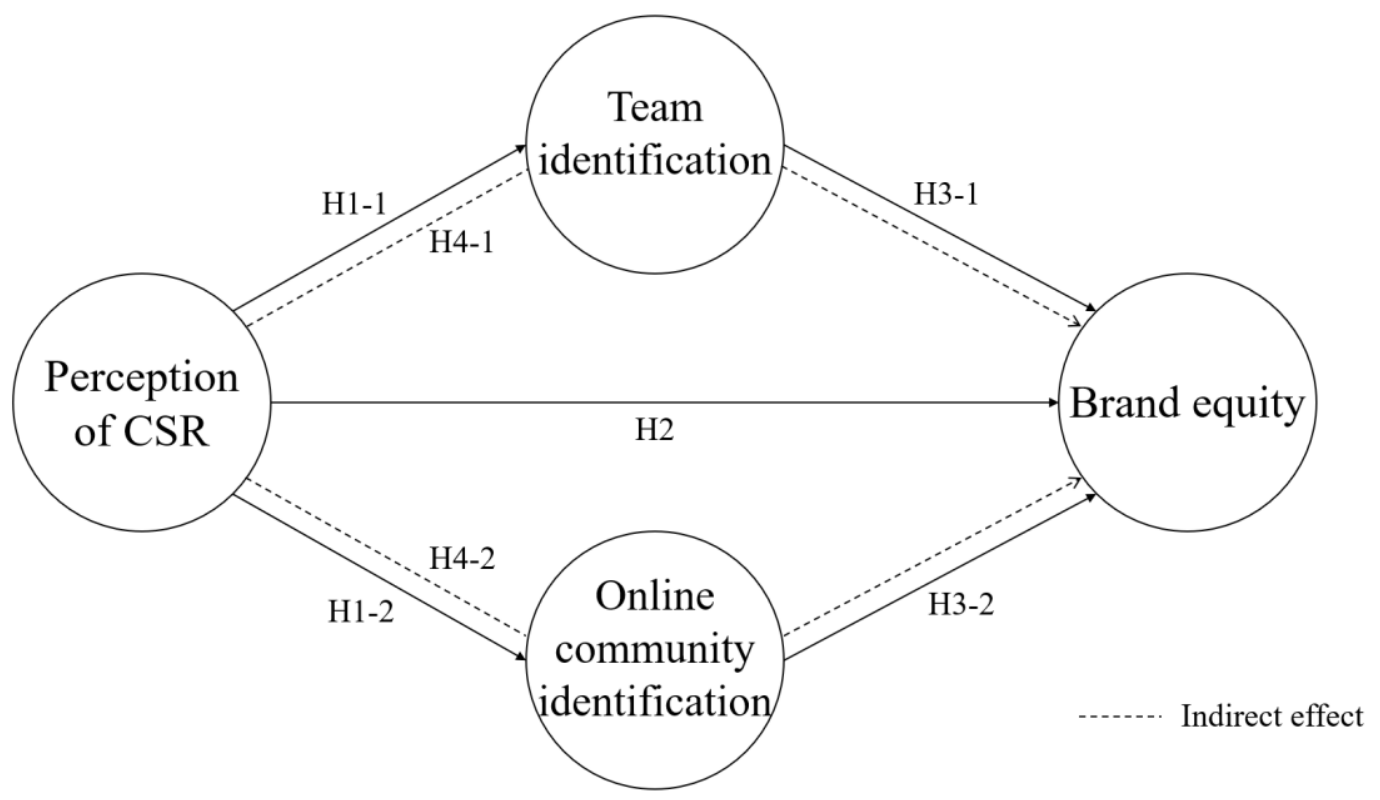

Figure 1.

Conceptual framework and hypotheses 